\title{
Dodatek k vybrané bibliografii Václava Blažka
}

Zde uvedené výstupy jsou pouze vědecké práce, pominuty jsou zcela bibliografické a biografické položky a recenze. Navazuje se číslováním na seznam, jak byl vytvořen Dufkovou (in print, 13-40).

\section{8 (pokračování)}

418. Turkické číslovky v zrcadle turkické dialektologie. In: Holub, Zbyněk, ed. Dialektologie

a geolingvistika v současné Střední Evropě III. Opava: Slezská univerzita v Opavě, 55-74.

419. Toward the Etymology of Latin littera. Graeco-Latina Brunensia 23(2), 5-11.

420. Tocharsko-slovanské lexikální paralely: nová srovnání. Linguistica Brunensia 66(2), 5-13. 421. (- Schwarz, Michal). On Tocharian Vessel-names with Special Regard to B lwake 'pot'. In: Kroonen, Guus - MAllory, James P. - Comrie, Bernard, eds. Talking Neolithic. Proceedings of the workshop on Indo-European origins held at the Max Planck Institute for Evolutionary Anthropology, Leipzig, December 2-3, 2013. Journal of Indo-European Studies Monograph Series 65. Washington, DC: Institute for the Study of Man, 24-38.

422. Cushitic numerals. Folia Orientalia 55, 33-60.

423. Baltic *auškléjas m. \& *auškléjá f. 'bleak'. Baltistica, Mintis 53(1), 99-112.

424. (- Schwarz, Michal). Altaic from the Point of View of Tungusic: Past \& Present State and Future Prospect. Turk Dilleri Araştımaları 28(2), 135-156.

\section{9}

425. Tocharian B lasto in Balto-Slavic Perspective. Journal of Indo-European Studies 47(1-2), 212-222.

426. Slavjanskoe *meč6ka 'medved'. Balto-slavjanskie issledovanija 20, 205-211.

427. How many words did the Indo-Europeans use? Wékwos 4, 57-82.

428. (- SchwArz, Michal - SRBA, Ondřej). Altaic Languages. History of research, survey, classification and a sketch of comparative grammar. Brno: Masaryk University Press.

429. Agamemnon. In: Giannakis, Georgios K. - Charalambakis, Christoforos - MontanaRI, Franco - Rengakos, Antonios, eds. Studies in Greek Lexicography, vol. 72, in Honor of John N. Kazazis. Berlin - Boston: de Gruyter, 119-130. 


\section{LITERATURA}

N

o

\section{Ondřej Šefčík}

Department of Linguistics and Baltic Languages

Faculty of Arts, Masaryk University

A. Nováka 1, 60200 Brno

Czech Republic

sefcik@phil.muni.cz 